\title{
Relationship between occlusion and dental attrition in a group of young Polish adults*
}

\section{Współzależność pomiędzy okluzją a atrycją w grupie polskich młodych dorosłych*}

\author{
Kinga Grzegocka ${ }^{1}$, Stephen Williams ${ }^{1}$, Jolanta E. Loster ${ }^{2}$, \\ Aneta Wieczorek ${ }^{2}$, Bartłomiej W. Loster ${ }^{1}$
${ }^{1}$ Katedra Ortodoncii, Instytut Stomatologii, Wydział Lekarski, Uniwersytet Jagielloński Collegium Medicum, Kraków, Polska Department of Orthodontics, Dental Institute, Faculty of Medicine, Jagiellonian University Collegium Medicum, Cracow, Poland Head: prof. B. W.Loster
2 Katedra Protetyki, Instytut Stomatologii, Wydział Lekarski, Uniwersytet Jagielloński Collegium Medicum, Kraków, Polska Department of Prosthodontics, Dental Institute, Faculty of Medicine, Jagiellonian University Collegium Medicum, Cracow, Poland Head: dr hab. G. Wiśniewska

\section{Abstract}

Aim of the study. To identify dental attrition in a group of young adults selected irrespective of occlusion. Classification of dental attrition was proposed and used to relate attrition to the type of occlusion observed simultaneously considering the subjective indication for orthodontic treatment as estimated by the evidence-based method derived by the Danish Ministry of Health. Materials and methods. The study material consisted of 250 plaster casts (69 males, and 181 females, average age $18 y 9 m$, max $20 y 9 m$, min $16 y 10 \mathrm{~m})$, included in the study irrespective of the type of occlusion they exhibited. All models were examined by one author (K.G.) recording molar and canine relationship, Angle's classification, maximum overjet and overbite, cingulum contact, midline shift, cross bite, scissors bite and open bite. Attrition was recorded using a classification assessing six tooth groups (maxillary/mandibular incisors, maxillary/mandibular canines, maxillary/mandibular buccal teeth) and three surfaces (incisal or occlusal, facial or buccal, palatal or lingual). A score system was developed and the tooth in each group seen to be most worn was selected to represent the segment. Results. 129 individuals (51.6\%) manifested dental attrition (38 males, 91

\section{KEYWORDS:}

occlusion, dental attrition, young adult

\section{Streszczenie}

Cel pracy. Ustalenie poziomu atrycji $w$ populacji szesnasto- dwudziestolatków wybranych do badania niezależnie od typu okluzji. Zaproponowano klasyfikację atrycji z jej powiazaniem z jednocześnie występujacym typem okluzji biorac pod uwage indywidualne wskazania do leczenia ortodontycznego ocenione na podstawie metody opartej na dowodach duńskiego ministerstwa zdrowia. Material i metody. Materiał badawczy stanowiło 250 odlewów gipsowych (69 mężczyzn i 181 kobiet), średnia wieku 18 lat 9 miesięcy, maksimum 20 lat 9 miesięcy, minimum 16 lat 10 miesięcy), które zostały właczone do badania niezależnie od posiadanego typu okluzji. Wszystkie modele zostaty przebadane przez jednego z autorów pracy (K.G.) oceniając wzajemna relacje trzonowców $i$ klów, klasyfikację Angle'a, maksymalny nagryz pionowy i poziomy, kontakt z cingulum, przesunięcie linii pośrodkowej, zgryz krzyżowy, zgryz przewieszony i zgryz otwarty. Zgodnie z klasyfikacja badano poziom atrycji $w$ sześciu grupach zębów (siekacze szczęki $i$ żuchwy, kły szczęki $i$ żuchwy, przedtrzonowce i trzonowce szczęki $i$ zuchwy) $i$ trzy powierzchnie (sieczna $i$ okluzyjna, wargowa lub policzkowa, podniebienna lub językowa). Opracowano system

\section{HASŁA INDEKSOWE:}

okluzja, atrycja, młodzi dorośli

\footnotetext{
* This study was supported by a grant from the Polish Ministry of Science and Higher Education to the Jagiellonian University Medical College, Cracow, Poland, as part of project no. N N403 589138.
} 
females). The most affected were incisal surfaces of maxillary and mandibular canines and incisal surface of mandibular incisors. The statistic analysis showed a higher attrition incidence in patients with forced bite and Class II div 2 malocclusion. Conclusions. The study demonstrates a high prevalence of dental wear in Polish young adults, especially in forced bite and Class II div 2 malocclusion. The risk of tooth wear should be considered as a valid reason to offer orthodontic treatment.

\section{Introduction}

Tooth wear is defined as "loss of dental hard tissue as a result of either a chemical or mechanical process not involving bacteria". ${ }^{1}$ It is well established that the prevalence of tooth wear varies in different populations and ethnic groups; it can also be related to dietary habits. ${ }^{2}$ Clinical experience shows that such "tooth wear" is relatively common and can be so severe that the vitality and survival of teeth can be in jeopardy. Such a situation is shown in Figure 1, where the degree of tooth abrasion clearly represents a threat to the teeth involved.

The pathogenesis of wear facets is considered to be multifactorial, with attrition, abrasion, corrosion and abfraction often acting synergistically rather than in isolation, more than one of the named mechanisms being frequently involved in the etiology of non-carious lesions. Updated and revised nomenclature definitions of tooth surface lesions were proposed by Grippo, ${ }^{3}$ according to whom attrition is defined as the result of tooth-to-tooth friction without any additional factors. Abrasion is caused by friction between a tooth and an exogenous agent, such as a food bolus, a toothbrush, dentifrice, dental floss, toothpicks, pens, pencils, clasps of partial denture etc. The reason for corrosion is a chemical or electrochemical action, arising from endogenous or exogenous sources. When dentine is exposed to the oral cavity environment, the chipped enamel can accelerate the development of caries by means of the so-called biocorrosion. Abfraction is said to punktacji, w którym najbardziej starty ząb $w$ danej grupie reprezentowat caty segment zębów. Wyniki. 129 osób (51,6\%) przejawiało atrycję (38 mężczyzn, 91 kobiet). W największym stopniu problem dotyczyt brzegów siecznych kłów w szczęce $i$ żuchwie $i$ siekaczy $w$ żuchwie. Analiza statystyczna wykazała wyższy poziom występowania atrycji u pacjentów ze zgryzem wymuszonym $i$ wada zgryzu klasy II/2. Wnioski. Badanie wykazało wysoki poziom starcia zębów Polaków w kategorii wiekowej 16-20 lat zwłaszcza $w$ przypadkach zgryzu wymuszonego $i$ wady klasy II/2. Ryzyko starcia zębów powinno być uznawane za wskazanie do leczenia ortodontycznego.

take place when excessive, cyclic, non-axial toothloading leads to cusp flexure, resulting in microfractures of dental tissue, particularly in the cervical region. ${ }^{3-5}$ Tooth wear can occur in the region of tooth cervix (non-carious cervical lesions, NCCLs) or on occlusal surfaces. Attrition, abrasion and corrosion contribute to the excessive wear of the occlusal and incisal areas, the lesions being flat, round or sharply angulated, polished and shiny and with dentine exposure. ${ }^{6-8}$ The regions most affected include the palatal surface of maxillary incisors, the incisal surfaces of mandibular incisors and functional cusps of upper and lower premolars and molars. Some wear is natural and progresses throughout life. The most significant risk factors for the progression of occlusal wear facets seems to be age, hard diet or chronic occlusal overload. ${ }^{2,3}$ It is also firmly established that anorexia nervosa, bulimia nervosa, gastro-esophageal reflux disease (GERD), ${ }^{9}$ and chronic alcoholism are strongly related to dental erosion. ${ }^{3,10}$ Attrition is severely aggravated in connection with excessive clenching and bruxism. ${ }^{11}$ Tooth wear is defined as pathological if the teeth become so worn that their functional role is impaired or the destruction seriously mars the appearance. ${ }^{12}$

Since there is both a clinical and a scientific need to be able to assess and register tooth wear, a number of methods have evolved to quantify tooth wear, the most popular being the "Tooth Wear Index (TWI)"13 or its modifications. ${ }^{12,14}$

Some investigations suggest that the nature of occlusal forces may be related to NCCLs, ${ }^{15}$ most 


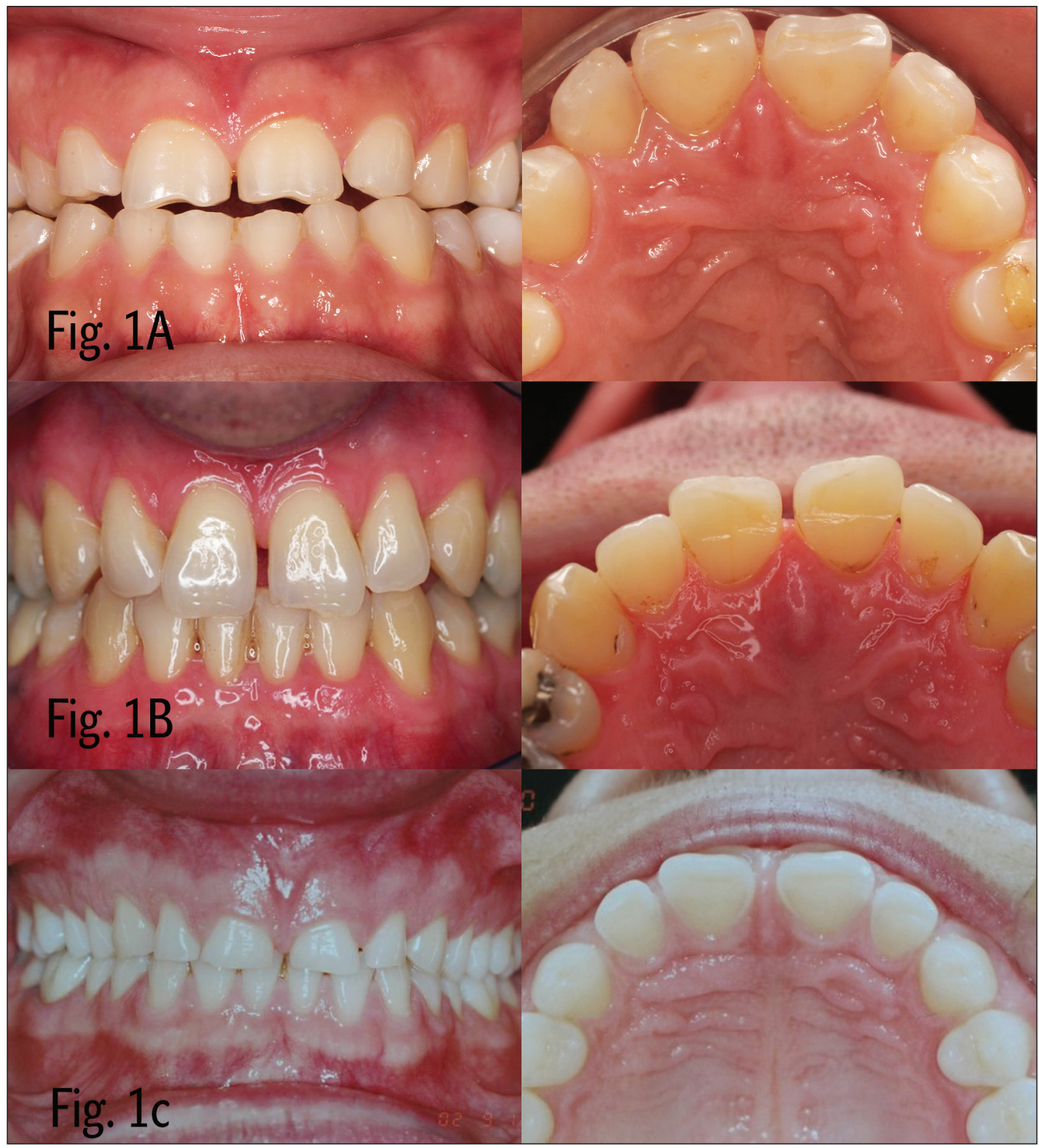

Fig. 1. Long-term effects of dental attrition in:

A - a 23-year-old female in connection with a naturally compensated Class III skeletal jaw pattern.

$B$ - the palatal surface of maxillary incisors in connection with deep bite occlusion and retroclination of maxillary incisors in a 40-year-old male.

$C$ - the maxillary incisors in a 40-year-old female as a result of an "edge to edge" occlusal relationship.

of the evidence supporting the association between occlusal stress forces and lesions in the region of the neck of the teeth described by finite element analysis (FEA) and laboratory studies ${ }^{16,17}$ though other studies have provided contradictory evidence as reported in the systematic review of Senna. ${ }^{18}$ According to Borcic et al., ${ }^{16}$ in cases demonstrating malocclusion, tensile stresses generated at the cervical areas appeared to be higher compared with the stresses generated in the case of normal 
occlusion. Other studies have also investigated a possible relationship between occlusal wear and temporomandibular joint disorders (TMD). ${ }^{7,8}$ Nonetheless, age, occlusal and attrition features were only moderately useful in differentiating between healthy patients and patients with TMD. 7,8

A review of the literature reveals many reports related to tooth wear facets, many of which describe the etiology, mechanism or epidemiology of the loss of dental tissue, $1,3,10,19$ though only few reports relate this event to malocclusion. ${ }^{6,7}$ Clinical experience demonstrates that even relatively young individuals show signs of dental attrition, most frequently in connection with malocclusion.

\section{The aim of the study}

The objective of this study was fourfold:

(1) to develop a simple classification system which could serve to register the location and severity of areas of dental attrition,

(2) to examine and evaluate the occlusion of the subjects chosen for examination and to assess their individual needs for orthodontic treatment,

(3) to investigate and report the extent and degree of attrition exhibited among the subjects selected,

(4) to investigate a possible relationship between dental attrition and various types of occlusion.

\section{Material and methods Material selection}

The present retrospective study is based on the examination and registration of study casts ground in habitual occlusion of 256 young adult students selected for a larger study relating temporomandibular function to occlusion. The subjects were selected irrespective of occlusion and examined in the Department of Orthodontics of the Jagiellonian University in Cracow (Poland). The plaster casts were ground and stored carefully to avoid damage. Six sets of casts were excluded from the study, five having had orthodontic brackets placed and one set being incorrectly ground. The total group consisted of 69 males, and 181 females with an average age $18 \mathrm{y} 9 \mathrm{~m}$ ( $\mathrm{max}$ $20 \mathrm{y} 9 \mathrm{~m}$, min 16y 10m). Of the subjects examined
121 (48.4\%) had previously received orthodontic treatment. Records taken in connection with the registration of the subjects indicate that all were healthy and did not suffer for any diseases or any syndrome which could influence enamel formation or strength.

\section{Registration of malocclusion}

All models manifesting malocclusion were examined critically by one author (K.G.) and a number of factors were recorded including molar and canine relationship, Angle classification, maximum overjet and overbite (in $\mathrm{mm}$ ), cingulum contact (yes/no) (contact of mandibular incisors on the cingulum of the maxillary incisors), midline shift $(\min 2.0 \mathrm{~mm})$, anterior cross bite and posterior cross bite (premolars and/or molars), scissors bite (premolars and/or molars), open bite, forced bite i.e. a differences between "centric relation" and "centric occlusion". Forced bite was assumed and recorded when a midline discrepancy was combined with cross bite or scissors bite.

Since the investigation was intended to examine attrition in relation to malocclusion, the occlusion of each set of study casts was assessed by one researcher (S.W.), as to the necessity of orthodontic treatment, blinded for previous orthodontic treatment and using an "evidencebased method" developed in connection with the selection of patients for orthodontic therapy in Danish municipal services.

\section{Development of a classification of attrition defining location and severity of sites of attrition}

A simple yet fully representative classification of each dental arch (maxillary and mandibular) was developed considering either one in three sections: the incisor segments, the canine segments and the right and left buccal segments combined (premolars and first molars). The presence and extent of attrition was examined on three surfaces (incisal/occlusal, facial/buccal, palatal/lingual) and the degree of attrition was recorded at four stages viz:

(1) Stage 0 - no wear visible;

(2) Stage 1-minimum tooth wear (insignificant change of tooth contour); 
(3) Stage 2 - tooth wear less than $50 \%$ of surface area;

(4) Stage 3 - tooth wear more or equal than $50 \%$ of the surface area.

Only the most worn tooth in each group was selected to represent the section. This evaluation was performed for each surface.

\section{Statistical analysis and presentation of results}

The material is examined in two stages:

(1) Stage 1 - the entire material was examined for sings of attrition and attrition was recorded according to location and severity in an Excel ${ }^{\circledR}$ table. This table was used to compare statistics regarding the patient with or without attrition.

(2) Stage 2 - data describing patients who show sings of attrition was selected from the Excel ${ }^{\circledR}$ table to form the basis of a study regarding location and severity of observed attrition. The patients selected comprised 129 individuals (38 males, 91 females).

Based on this data the frequency of observed attrition related to locationi.e. tooth group according to the proposed classification is demonstrated in Figure 2. Figure 3 demonstrates the frequency and severity (level 1,2,3) of attrition related to the dental surfaces involved.

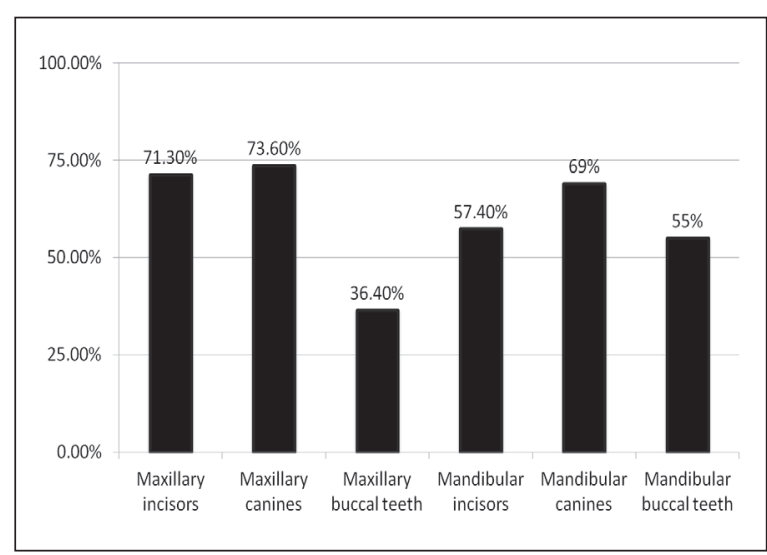

Fig. 2. Distribution of teeth showing signs of attrition.

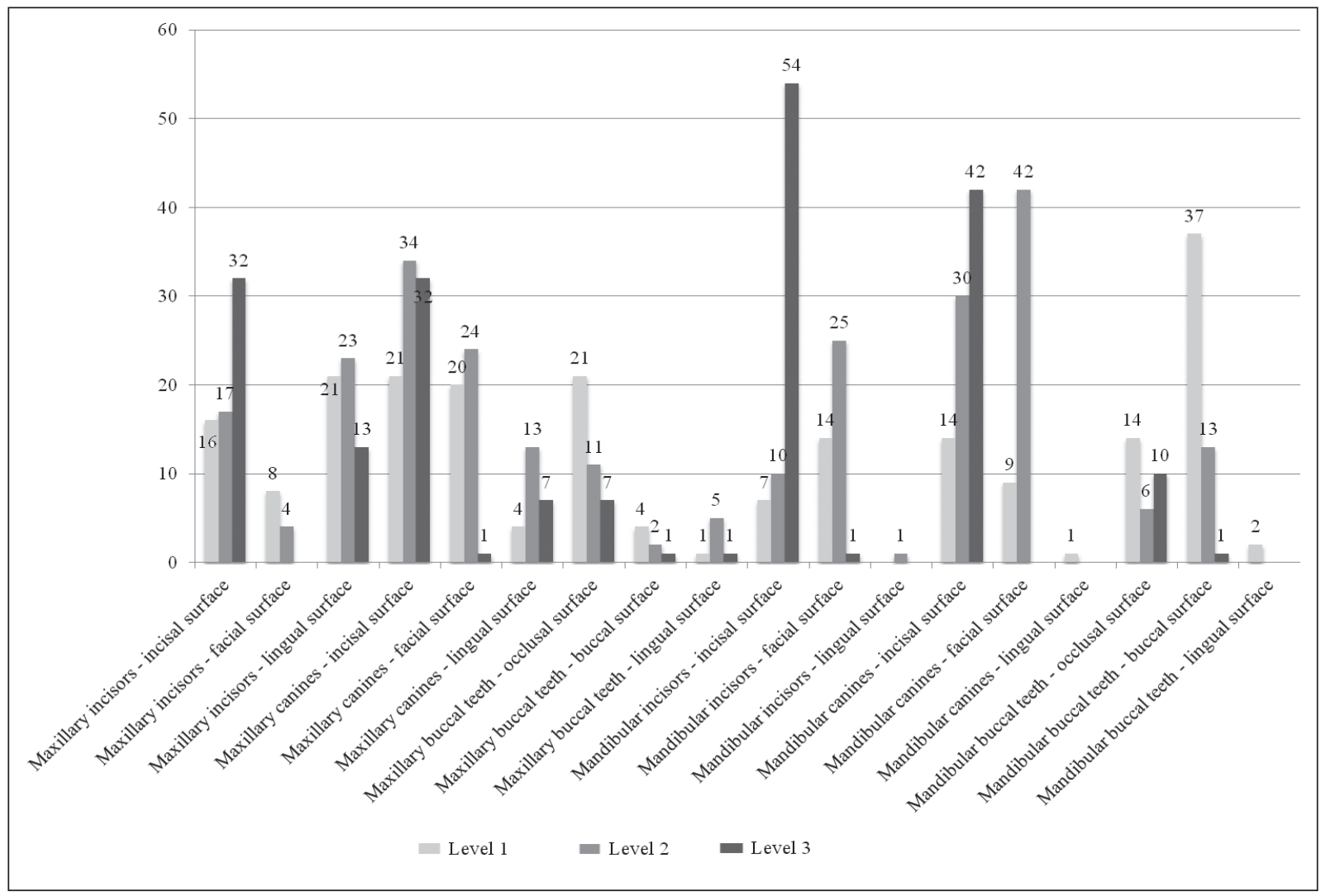

Fig. 3. Location and severity (level I, 2, 3) of observed attrition among all subjects ( $N=129)$. 
Based on the entire material (i.e. 250 individuals) the observation of attrition (yes/no) related to malocclusion was tested by means of chi squared independence test. The results are presented in Table 1. This table also relates attrition to the treatment indication decision as expressed by "evidence-based method" as defined by Danish Stated Authorities.

A full multivariate logistic regression ${ }^{20}$ adjusted by age and gender was performed in order to support the hypothesis of a relationship between selected occlusal factors and tooth attrition. The results including the "Odds Ratio" (OR) and the 95 percent confidence intervals were calculated and are shown in Table 2.

Analyses were performed using the statistical packet SPSS Software (IBM, Armonk, NY). Statistical significance was accepted at the level $\mathrm{p}<0.05$.

This study was approved by the bioethics committee of the Jagiellonian University, Cracow with the approval certificate number KBET/89/B/2009.

\section{Results}

Of the models of the 250 late adolescent students included in the study 129 individuals (51.6\%) presented at least one sign of attrition (38 males, 91 females) and 91 (36.4\%) had one or more teeth worn at level 3.

The results shown in Figure 2 illustrate that tooth wear was most frequently observed in groups of maxillary canines $(73.6 \%)$, maxillary incisors (71.3\%), mandibular canines (69\%), mandibular incisors (57.4\%), mandibular buccal teeth (55\%) and the least frequently in the group comprising maxillary buccal teeth (36.4\%).

The location and severity of the observed attrition illustrated in Figure 3 show that the most affected surfaces were the incisal surfaces of the maxillary and mandibular canines ( 87 and 86 observations respectively), the incisal surface of the mandibular and maxillary incisors (71 and 65 observations respectively). The most severe degree of attrition (level 3) was observed on incisal surfaces of the mandibular incisors (54 observations) and mandibular canines (42 observations).
The distribution of prevalence of tooth attrition in the registered malocclusion was tested by means of a chi-squared test using both numerical frequency and percentage in relation to individuals with and without attrition. The results are shown in Table 1. There was no significant difference in percentage of tooth attrition between men and women. There were more individuals with tooth attrition in Angle Class II malocclusion with retrusion of maxillary incisors (75.0\%) when compared with Class III (33.33\%) and Class I (47.86\%). A similarly statistically significant relationship was seen in individuals with forced bite. There was no significant frequency of tooth attrition in connection with midline shift, decreased overjet, increased overbite, cingulum contact, cross bite or scissors bite.

Data describing the relationship between attrition and malocclusion obtained by multivariate logistic regression adjusted for age and gender is shown in Table 2. Again the prevalence of tooth attrition was significantly higher in Angle Class II div 2 malocclusion $(\mathrm{OR}=3.10,95 \% \mathrm{Cl} 1.10$ 8.75) compared with Class I individuals. Subjects suspected of a "forced bite" functional pattern appeared to have a greater risk $(\mathrm{OR}=4.26,95 \% \mathrm{Cl}$ 1.28-14.19) of dental attrition. Statistically, other occlusal factors were not significantly associated with tooth attrition.

\section{Discussion}

Clinical evidence points to the fact that dental wear, if extreme, represents a risk to the dentition and even in some cases to the occlusion. Understanding of the potential risk of serious attrition, and in particular identifying individuals who demonstrate a risk factor, represents therefore an important step in the establishment of good and long lasting oral health.

The design of the present study is retrospective, which avoids the time problems of a long-time prospective study, but is burdened with the usual problems which accompany a retrospective study. Factors such as dietary habits or a true evaluation of the functional pattern including bruxism, all of which represent features which are known to influence tooth wear, could not be investigated. The study does, however, illustrate that a significant 
Table 1. The results of chi-squared test relating observed attrition and various malocclusion traits

\begin{tabular}{|c|c|c|c|}
\hline \multirow{2}{*}{ Variable } & \multicolumn{2}{|c|}{ Attrition } & \multirow{2}{*}{$p$} \\
\hline & Yes & No & \\
\hline \multicolumn{4}{|l|}{ Gender } \\
\hline Male & 38 (55.07\%) & 31 (44.93\%) & \multirow{2}{*}{0.497558} \\
\hline Female & 91 (50.28\%) & $90(49.72 \%)$ & \\
\hline \multicolumn{4}{|l|}{ Previous treatment } \\
\hline Yes & $63(52.07 \%)$ & $58(47.93 \%)$ & \multirow{2}{*}{0.886426} \\
\hline No & $66(51.16 \%)$ & $63(48.84 \%)$ & \\
\hline \multicolumn{4}{|l|}{ EBM } \\
\hline Treatment & $57(56.44 \%)$ & $44(43.56 \%)$ & \multirow{3}{*}{0.326589} \\
\hline No-Treatment & $19(54.29 \%)$ & $16(45.71 \%)$ & \\
\hline Minor Discrepancy & $53(46.49 \%)$ & $61(53.51 \%)$ & \\
\hline \multicolumn{4}{|l|}{ Angle Classification } \\
\hline Class 1 & $56(47.86 \%)$ & 61 (52.14\%) & \multirow{4}{*}{0.005237} \\
\hline Class II div 1 & 38 (59.38\%) & $26(40.63 \%)$ & \\
\hline Class II div 2 & $21(75.00 \%)$ & $7(25.00 \%)$ & \\
\hline Class III & $11(33.33 \%)$ & $22(66.67 \%)$ & \\
\hline \multicolumn{4}{|l|}{ Midline shiff } \\
\hline On & $65(48.87 \%)$ & $68(51.13 \%)$ & \multirow{2}{*}{0.357481} \\
\hline Off & $64(54.70 \%)$ & $53(45.30 \%)$ & \\
\hline \multicolumn{4}{|l|}{ Overiet $\leq 2.0 \mathrm{~mm}$} \\
\hline № & $107(52.71 \%)$ & $96(47.29 \%)$ & \multirow{2}{*}{0.559517} \\
\hline Yes & $22(47.83 \%)$ & $24(52.17 \%)$ & \\
\hline \multicolumn{4}{|l|}{ Overbite $\geq 5.0 \mathrm{~mm}$} \\
\hline No & $113(50.00 \%)$ & $113(50.00 \%)$ & \multirow{2}{*}{0.07361} \\
\hline Yes & $22(47.83 \%)$ & $24(52.17 \%)$ & \\
\hline \multicolumn{4}{|l|}{ Cingulum contact } \\
\hline No & 91 (49.73\%) & $92(50.27 \%)$ & \multirow{2}{*}{0.327338} \\
\hline Yes & $38(56.72 \%)$ & $29(43.28 \%)$ & \\
\hline \multicolumn{4}{|l|}{ Forced bite } \\
\hline No & 108 (49.09\%) & 112 (50.91\%) & \multirow{2}{*}{0.031574} \\
\hline Yes & $21(70.00 \%)$ & $9(30.00 \%)$ & \\
\hline \multicolumn{4}{|l|}{ Cross bite } \\
\hline No & $102(52.04 \%)$ & $94(47.96 \%)$ & \multirow{2}{*}{0.790461} \\
\hline Yes & $27(50.00 \%)$ & $27(50.00 \%)$ & \\
\hline \multicolumn{4}{|l|}{ Scissors bite } \\
\hline No & $121(50.63 \%)$ & 118 (49.73\%) & \multirow{2}{*}{0.151559} \\
\hline Yes & $8(72.73 \%)$ & $3(27.27 \%)$ & \\
\hline
\end{tabular}


Table 2. The results of full-multivariate logistic regression adjusted to age and gender for individuals with attrition

\begin{tabular}{|c|c|c|}
\hline Variable & OR 95\% & $p$ \\
\hline \multicolumn{3}{|c|}{ Previous treatment } \\
\hline Yes & 1 & \\
\hline No & $0.91(0.52-1.58)$ & 0.7279474 \\
\hline \multicolumn{3}{|c|}{ Angle Classification } \\
\hline Class I & 1 & \\
\hline Class II div 1 & $1.91(0.93-3.92)$ & 0.07715912 \\
\hline Class II div 2 & $3.10(1.10-8.75)$ & 0.03174374 \\
\hline Class III & $0.48(0.19-1.19)$ & 0.1113882 \\
\hline \multicolumn{3}{|l|}{ Midline shift } \\
\hline On & 1 & \\
\hline Off & $0.83(0.44-1.56)$ & 0.557465 \\
\hline \multicolumn{3}{|l|}{ Overiet } \\
\hline$>2.0 \mathrm{~mm}$ & 1 & \\
\hline$\leq 2.0 \mathrm{~mm}$ & $0.92(0.43-1.99)$ & 0.8353731 \\
\hline \multicolumn{3}{|l|}{ Overbite } \\
\hline$<5.0 \mathrm{~mm}$ & 1 & \\
\hline$\geq 5.0 \mathrm{~mm}$ & $2.11(0.70-6.39)$ & 0.1835188 \\
\hline \multicolumn{3}{|l|}{ Cingulum contact } \\
\hline No & 1 & \\
\hline Yes & $0.88(0.45-1.71)$ & 0.6956297 \\
\hline \multicolumn{3}{|l|}{ Forced bite } \\
\hline No & 1 & \\
\hline Yes & $4.26(1.28-14.19)$ & 0.01784326 \\
\hline \multicolumn{3}{|l|}{ Cross bite } \\
\hline No & 1 & \\
\hline Yes & $0.70(0.31-1.59)$ & 0.3965199 \\
\hline \multicolumn{3}{|l|}{ Scissors bite } \\
\hline No & 1 & \\
\hline Yes & $1.33(0.27-6.68)$ & 0.7261288 \\
\hline
\end{tabular}


proportion of individuals demonstrate tooth wear by adolescence: as many as $51.6 \%$ show sign of dental attrition and $36.4 \%$ demonstrate attrition at clinically significant level. Since a few of the subjects have received previous orthodontic treatment at an earlier stage it is not absolutely certain whether the observed dental wear was a result of the earlier malocclusion, the orthodontic therapy or the post-orthodontic occlusion. These findings alone represent a justification for the present study, but cannot be generalized to the Polish population since the material used is restricted and not totally randomly chosen. NonCarious Cervical Lesions (NCCL's) were not included in the present study.

The results of the study demonstrate the susceptibility to dental attrition of individuals with Class II div 2 malocclusion as well as those suspected of having a "forced bite". Deep bite as such did not seem to pose a statistically significant higher risk of dental wear, which could indicate that deep bite in connection with "tight incisal occlusion", which characterizes a Class II div 2 anomaly, represents an additional risk factor. This finding could indicate that the etiology of tooth wear is multifactorial or that a deep bite represents a risk only where the incisal contact is "tight" as is characteristic in the Class II div 2 malocclusion. This finding seems to be logical, but no references could be found in the literature.

It had been anticipated, based on clinical experience, that anterior open bite could be associated with attrition in the buccal segment. Though five subjects with open bite were included in the material, of whom three showed attrition, this group was too small for statistic calculation.

It was likewise anticipated that the compensated Class III malocclusion would represent a risk factor for dental wear as is seen in Figure $1 \mathrm{AB}$ in the introduction. It is likely that the tightness of the reverse overjet as seen in Figure 1A could result in dental wear, so that in cases of a severe Class III malocclusion with no incisal contact, no dental damage will be observed.

Interpreting the results of this study it can be hypothesised that there exist two different types of attrition. Type I attrition could represent a type of morphological adaptation enabling the creation of a functional pattern such as the "canine rise" seen in mandibular laterotrusion. The question arises as to whether this type of attrition is progressive and could threaten the dentition or the occlusion at a later stage. Type II attrition represents a type of tooth wear resulting from malfunction and in all probability could be progressive and result in clinical problems both to single teeth and the occlusion. The type of attrition seen in connection with deep bite and retroclined maxillary incisors in connection with the Class II div 2 malocclusion is more likely to be pathological and reflects an aberrant functional pattern which, if persistent, will lead to clinically significant destruction. This type of attrition is also highly likely to occur in connection with over compensation of skeletal sagittal discrepancies, in particular Class III discrepancy which is the cause of the problem in Figure 1AB.

The present study draws attention to the risk of attrition of the dentition with a possible deleterious effect on individual teeth and the occlusion. The report draws attention to the role of malocclusion in the development of attrition, and underlines that such tooth wear should be taken into account if observed in a young individual considering orthodontic treatment. There is no doubt that attrition seen in adult orthodontic patients, as demonstrated in Figure 1, is related to malocclusion and apparently seems more significant because of the age of the individual. The results of this study indicate the necessity for a follow-up study on an older population so that the risk of tooth wear over a longer period can be clearly evaluated.

\section{Conclusions}

(1) The present study demonstrates a high prevalence of dental attrition in relatively young Polish adults, especially in the case of forced bite and Class II div 2 malocclusion. There are no differences in frequency of attrition comparing females and males.

(2) As a consequence of the risk of tooth wear, especially if observed in a young person, the advisability of offering orthodontic treatment aimed at modification of occlusion should be considered. 


\section{References}

1. Eccles JD: Tooth surface loss from abrasion, attrition and erosion. Dent Update 1982; 9: 373381 .

2. Tollaro I, Defraia E, Marinelli A, Alarashi M: Tooth abrasion in unilateral posterior crossbite in the deciduous dentition. Angle Orthod 2002; 72: 426-430.

3. Grippo JO, Simring M, Schreiner S: Attrition, abrasion, corrosion and abfraction revisited. A new perspective on tooth surface lesions. J Am Dent Assoc 2004; 135: 1109-1118.

4. Michael JA, Townsend GC, Greenwood LF, Kaidonis JA: Abfraction: separating fact from fiction. Aust Dent J 2009; 54: 2-8. doi: 10.1111/j.1834-7819.2008.01080.x.

5. Antonelli JR, Hottel TL, Garcia-Godoy F: Abraction Lesions - Where do They Come From? A Review of the literature. J Tenn Dent Assoc 2013; 93: 14-19.

6. Cunha-Cruz J, Pashova H, Packard JD, Zhou L, Hilton TJ: Tooth wear: prevalence and associated factors in general practice patients. Community Dent Oral Epidemiol 2010; 38: 228-234. doi: 10.1111/j.1600-0528.2010.00537.x.

7. Seligman DA, Pullinger AG: Analysis of occlusal variables, dental attrition, and age for distinguishing healthy controls from female patients with intracapsular temporomandibular disorders. J Prosthet Dent 2000; 83: 76-82.

8. Pullinger AG, Seligman DA, Gornbein JA: A multiple logistic regression analysis of the risk and relative odds of temporomandibular disorders as function of common occlusal features. J Dent Res 1993; 72: 968-979.

9. Howden GF: Erosion as the representing symptom in hiatus hernia: a case report. Br Dent J 1997; 131: 455-456

10. Smith $B G$, Bartlett $D W$ : The prevalence, etiology and management of tooth wear in the United Kingdom. J Prosthet Dent 1997; 78: 367-372.

11. Diraçoğlu D, Alptekin K, Cifter ED, Güçlü $B$, Karan A, Aksoy $C$ : Relationship between maximal bite force and tooth wear in bruxist and non-bruxist individuals. Arch Oral Biol 2011; 56: 1569-1575.

12. Bardsley $P F$ : The evolution of tooth wear indices. Clinical and Oral Investigation 2008; 12: 5S-19S.

13. Smith BG, Knight JK: An index for measuring the wear of teeth. Br Dent J 1984; 156: 435-438.

14. Hooper SM, Meredith $N$, Jagger DC: The development of new index for measurement of incisal/occlusal tooth wear. J Oral Rehabil 2004; 31: 206-212.

15. Estafan A, Furnari PC, Goldstein G, Hittelman E: In vivo correlation of noncarious cervical lesion and occlusal wear. J Prosthet Dent 2005; 93: 221 226.

16. Borcic J, Anic I, Catic A, Miletic I, Pezelj S: 3D finite element model and cervical lesion formation in normal occlusion and in malocclusion. J Oral Rehabil 2005; 32: 504-510.

17. Zou L, Cherukara G, Hao O, Seymour K, Samarawickrama DYD: Geometric of tooth wear. Wear 2006; 266: 205-208.

18. Senna P, Del Bel Cury A, Rösing C: Non-carious cervical lesions and occlusion: a systematic review of clinical studies. J Oral Rehabil 2012; 39: 450462.

19. Benazzi S, Nguyen HN, Schultz D, Grosse IR, Gruppioni G, Hublin JJ, et al.: The evolutionary paradox of tooth wear: simply destruction or inevitable adaptation? PLoS One 2013; 8: e62263. doi: 10.1371/journal.pone.0062263.

20. Agresti A: An Introduction to Categorical Data Analysis. 2nd ed. New Jersey: Wiley-Interscience; 2007. p. 34-41, 99-121.

Address: 31-155 Kraków, ul. Montelupich 4 Tel.: +48 12 4245402, Fax: +48 124245494

e-mail: kinga.grzegocka@uj.edu.pl

Received: 31st December 2015

Accepted: 23rd August 2016 